\title{
The genus Cneorane Baly, 1865 from Taiwan (Coleoptera: Chrysomelidae: Galerucinae), with notes on sexual dimorphism and its life history
}

\author{
Chi-Feng Lee ${ }^{1 *}$ and Jan Bezděk ${ }^{2}$
}

\begin{abstract}
Background: Three species of the genus Cneorane Baly, 1865 are recorded originally from Taiwan: C. femoralis Jacoby, 1888, C. rugulipennis (Baly, 1886), and C. violaceipennis Allard, 1889.

Results: The result indicates that C. elegans Baly, 1874 (= C. rufipes Weise, 1889, syn. nov. and C. cyanipennis Chûjô, 1938, syn. nov.), C. violaceipennis Allard, 1889 (= C. fokiensis Weise, 1922, syn. nov.), and C. rugulipennis Baly, 1886 ( = C. femoralis Jacoby, 1888, syn. nov. and C. formosana Weise, 1922) are recognized. Cneorane violaceipennis, misidentified as C. elegans for more than 100 years, is redefined and recorded from Taiwan for the first time. Sexually dimorphic characters and diagnostic ones for each species are addressed. The life histories of Cneorane species are noted. Lectotypes are designated for C. violaceipennis Allard, 1889, C. femoralis Jacoby, 1888, and C. cyanipennis Chûjô, 1938.
\end{abstract}

Conclusions: The present state of taxonomic study on this genus is insufficient. However, it can be improved if variable characters are detected and sexually dimorphic characters are found by examining sufficient material.

Keywords: Taxonomy; New species; Leaf beetles

\section{Background}

The genus Cneorane Baly, 1865 contains mostly paleotropical species that were described in the nineteenth century (Wilcox 1971). A revision of the genus is still extant but keys are available for different areas. Although a key to all Oriental species was presented by Medvedev (2011), the distributions, colors of the antenna, legs, and ventral side are major components of that key which are considered variable within the same species in some cases.

Cneorane formosana Weise 1922 was first recorded and described from Taiwan and later synonymized with C. femoralis Jacoby 1888 by Kimoto (1965b). The second Taiwanese species, C. cyanipennis, was described by Chûjô (1938). It was synonymized with C. violaceipennis Allard 1889 by Kimoto (1969). However, Medvedev (2011) indicated that $C$. cyanipennis should be a distinct species based on the smaller size and black tibiae. The third recorded species, C. rugulipennis Baly 1886, was first published from Taiwan by Chûjô (1935). This species,

\footnotetext{
*Correspondence: chifeng@tari.gov.tw

${ }^{1}$ Applied Zoology Division, Taiwan Agricultural Research Institute, 189

Chung-Cheng Road, Taichung 413, Wufeng, Taiwan

Full list of author information is available at the end of the article
}

subsequently also recorded by Kimoto (1969, 1989a), can be separated from $C$. femoralis by the sculpturing of the elytra (Kimoto and Takizawa 1997) (smooth interstices between elytral punctures in C. rugulipennis and shagreened ones in C. femoralis). However, Gressitt and Kimoto (1963) indicated that both character states represent sexual dimorphism of $C$. femoralis. In order to clarify species identities, diagnostic and sexually dimorphic characters of each species need to be reevaluated by examining extensive collections. Types of most available names should be reexamined to confirm their taxonomic status, especially for C. elegans Baly 1874 and C. fokiensis Weise 1922 which are most relevant to Taiwanese species.

Biological information of this genus is little known. The larva of C. violaceipennis rufipes Weise 1889 (= C. elegans Baly 1874) was described by Medvedev and Zaitzev (1977). Biological notes and the larva of C. intermedia Fairmaire, 1889 were presented by Zaitzev and Dap (1982). In addition, historic collections of Taiwanese species revealed that males are apparently rare and only collected in spring. Moreover, sexual dimorphism for some species has not been mentioned perhaps because of the general lack of males. Laboratory rearing and 
field observations can provide needed biological information. The reason why males are perhaps rare and only collected in spring may be explained by associations of the phenology of host plants with the life history of Cneorane species.

\section{Methods}

A population of C. rugulipennis was found in October 2008 in Wulai Township (Taipei County, northern Taiwan), in a deciduous forest at an elevation of 120 to $500 \mathrm{~m}\left(121^{\circ} 33 \mathrm{E}\right.$, $24^{\circ} 52 \mathrm{~N}$ ). Field observations investigating the life history were made over 1 year. Females were taken to the laboratory for rearing in October. One infested host plant was transferred to the laboratory to observe pupation.

To prepare drawings of the adult reproductive systems, the abdomens of adults were separated and boiled in a $10 \%$ $\mathrm{KOH}$ solution, cleared in distilled water, and then mounted on slides with glycerin. Slides were examined using a Leica M165 stereomicroscope (Leica microsystems, Singapore, Singapore), and figures were drawn using a Nikon ECLIPSE 50i microscope (Melville, NY, USA).

Studied specimens were deposited in the following institutes, museums, and private collections: BMNH, Natural History Museum, London, UK (Maxwell V. L. Barclay); DEI, Senckenberg Deutsches Entomologisches Institut, Müncheberg, Germany (Stephan M. Blank); EUMJ, Ehime Univ., Matsuyama, Japan (Hiroyuki Yoshitomi); JBBC, Jan Bezděk collection, Brno, Czech Republic; KMNH: Kitakyushu Museum of Natural History and Human History, Kitakyushu, Japan (Kyoichiro Ueda); MCZC, Museum of Comparative Zoology, Harvard Univ., Cambridge, MA, USA (Philip D. Perkins); MNHN, Muséum National d'Histoire Naturelle, Paris, France (Antoine Mantilleri); MNHUB, Museum für Naturkunde, Leibniz-Institut für Evolutions und Biodiversitätsforschung an der Humboldt-Univ. zu Berlin, Berlin, Germany (Joachim Willer, Johannes Frisch); NHRS, Naturhistoriska Riksmuseet, Stockholm, Sweden (Johannes Bergsten); NMNS, National Museum of Natural Science, Taichung, Taiwan (Ming-Luen Jeng); RBNN, Ron Beenen collection, Nieuwegein, the Netherlands; and TARI, Taiwan Agricultural Research Institute, Taichung, Taiwan.

This taxonomic paper is registered in the ZooBank as a requirement for the established Official Register of Zoological Nomenclature (http://zoobank.org/References/ D3ABC845-AA71-4223-9EC4-812DA441843F).

\section{Results and discussion}

\section{Cneorane elegans Baly}

The following names are synonymies of Cneorane elegans Baly:

- Cneorane elegans Baly 1874: 182 (Japan); Fairmaire 1887: 332 (China: Beijing); Heyden 1887: 283 (Korea);
Chûjô 1940: 109 (Japan: Shikoku); Chûjô and Kimoto 1961: 161 (catalog); Kimoto 1965a: 375 (list).

- Cneorane violaceipennis Gressitt and Kimoto 1963: 553 [misidentification] (Russia: Siberia; China: Hebei, Gansu, Shaanxi, Jiangsu, Anhui, Zhejiang, Fujian, Jiangxi, Hubei, Guangdong, Sichuan; Korea); Kimoto 1969: 35 (Taiwan); Kimoto 1986: 57 (Taiwan); Kimoto 1989a: 252 (Taiwan); Takizawa et al. 1995: 9 (Taiwan); Yu et al. 1996 (China). Cneorane rufipes Weise 1889: 620 (China: Jiangsu); Jacoby 1890: 193 (China). New synonym (syn. nov.).

- Cneorane violaceipennis rufipes Ogloblin 1936: 215 [misidentification] (China: Heilongjiang, Hebei, Jiangsu, Sichuan; Korea; Russia: Ussuri); Chûjô 1941a: 158 (Korea); Chûjô 1941b: 461 (Korea). Cneorane elegans var. violaceipennis - Baly 1890: 14 (downgraded as a variety of C. elegans).

- Cneorane elegans ab. violaceipennis Weise 1924: 126 (list).

- Cneorane cyanipennis Chûjô 1938: 135 (Taiwan); Chûjô 1962: 206 (redescription); Chûjô 1965: 93 (Taiwan); Kimoto 1966: 29 (Taiwan); Kimoto 1969: 35 (synonymized with C. violaceipennis); Medvedev 2011: 365 (status revived). syn. nov.

\section{Type material}

The following are the type materials for every species:

- Cneorane elegans - Holotype female () (BMNH), labeled: "Cneorane elegans Baly Japan (pale blue label)/Baly coll".

- Cneorane rufipes - Lectotype + (MNHUB), labeled: "Kan-ssu 1885 G. Patanin [sic!]/Cneorane rufipes Ws/SYNTYPES Cneorane rufipes Weise 1889 labelled by MNHUB 2012 (red label)". Number of paralectotypes is unknown.

- Cneorane cyanipennis - Lectotype + , here designated, labeled: "TAIHEIZAN (= Taipingshan, Ilan) FORMOSA 9.VII.1933 COL. M. CHUJO/ COType (circle label with yellow letters)/Cneorane cyanipennis CHÛJÔ DET. M. CHUJO/1363" (TARI). Paralectotypes: 3 우, with same data as for lectotype, but with "1360-1362" (TARI) respectively; 1 o, same but with "23-V-1931 Col. R. Takahashii/ 1899" (TARI); 1 ㅇ, same but with "Jul. $1930 \mathrm{~S}$. Minowa/1900" (TARI); 1 ㅇ, same but with " 25 VIII1923 Col. T. Shiraki” (TARI).

\section{Specimens examined}

The specimens examined $(n=176)$ in different areas are listed below:

- China: 1 + , Heilongjiang, Sunwu, 10 July 1940, leg. H. Takahasi (TARI); 1 +, Laioning, Anzan (= Anshan), 
18 July 1935, leg. M. Yamada (TARI); 1 male (ふ), 1 q, Shandong, Tsingtao, Laoshan, 26 June 1957, leg. Y. Yano (TARI); 1 ㅇ, Shanxi, Jiang County, 4 Aug. 1972, leg. S. Y. Wang (TARI)

- Japan: 2 우, Shikoku, Kooti-Ken, 23 June 1934, leg. I. Okubo (TARI)

- North Korea: 1 ㅇ, Ranan (= Nanam), 14 to 15 Aug. 1933, leg. K. Nomura (TARI)

- South Korea: 1 q, Keijo (= Seoul), 13 July 1957, leg. Y. Yano (TARI); 1 q, Keikido, Keizyo, Sankakuzan, 6 Aug. 1937, leg. M. Yamada (TARI); 2 ふふ઼, 3 우, Keikido, Suigen, 16 May 1935, leg. D. Oxamoto (TARI); 1 đ̃, Keishohokudo, Mt. Kinuzan, 25 June 1932, leg. Umeno and Yamauchi (TARI)

- Taiwan: 1 ô, Chiayi, Arishan (=Alishan), 3 May 1917, leg. T. Shiraki (TARI); 1 गे, same locality, 23 May 1981, leg. K. Sasagawa (EUMJ); 1 ふै, same locality, 12 May 2011, C.-F. Lee (TARI); 1 ㅇ, Chiayi, Funkiko (=Fenchihu), 29 Aug. 1949, leg. C. T. Lin (TARI); 1 9, same but with "1.IX.1949" (TARI); 1 ㅇ, same locality, 23 Aug. 1968, leg. M. Nishikawa (EUMJ); 1 , , same locality, 25 to 26 Apr. 1986, leg. C.S. Lin (NMNS); 1 ㅇ, Hualien, Karapao, 14 Aug. 1940, leg. M. Chujo (TARI); 1 , Hualien, Seraoka, 15 Aug. 1940, leg. M. Chujo (TARI); 3 우, Hualien, Sikiyan (= Hsuchiachan), 16 Aug. 1940, leg. M. Chujo (TARI); 4 우, Ilan, Ssuchi, 1 Aug. 2009, leg. M.-H. Tsou (TARI); 2 ふิ઼, 3 웅, same locality, 19 May 2010, leg. H.-J. Chen (TARI); 1 Ĵ, Ilan, Taiheizan (= Taipingshan), July 1930, leg. S. Minowa (TARI); 3 q, , same locality, May 1935, leg. Y. Miwa (TARI); 1 , same locality, 17 July 1940, leg. M. Chujo (TARI); 1 \%, same locality, 8 Aug. 1989, leg. K. W. Huang (NMNS); 2 ふึ,, 2 우, Kaohsiung, Sekizan (=Shihshan), 11. Apr. 1976, leg. K. Ushijima (EUMJ); 7 q $q$, Kaohsiung, Tengchih (= Shihshan logging trail), 22 Aug. 1996, leg. M. L. Chan (NMNS); 1 q, same locality, 2 to 5 June 2008, leg. C.-F. Lee (TARI); 19 우, same but

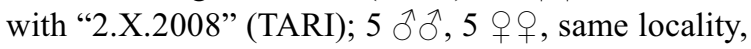
24 Mar. 2009, leg. S.-F. Yu (TARI); 1 , same locality, 26 May 2009, C.-F. Lee (TARI); 1 , same locality, 4 July 2011, leg. M.-H. Tsou (TARI); 1 ㅇ, Nantou, Baibara (= Meiyuan), 4 to 7 July 1939, leg. Y. Miwa (TARI); 1 $\hat{\text {, }}$, Nantou, Musha (= Wushe), 18 May to 15 June 1919, leg. T. Okuni (TARI); 2 우우, same locality, 25 June-5 July 1947, leg. Maa, Chen and Lin (TARI); 1 , , Nantou, Namakaban (= Lona), 8 Aug. 1925, leg. M. Kato (TARI); 1 , Nantou, Pihu, 26 Sept. 2011, leg. J.-C. Chen (TARI); 1 ふૈ, Nantou, Sankakuho (= Meifeng), 25 May 1927, leg. K. Fukuda (TARI); 1 , 7 to 9 May 1981, leg. K.S. Lin and S.C. Lin (TARI); 1 ô, Nantou, Shanlinchi,

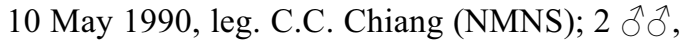

Nantou, Sungkang, 8 to 9 May 1978, leg. N. Yashiro (EUMJ); 1 đ̄, Nantou, Sungkang, Tsuifeng, 3 June 1981, leg. K. Sasagawa (EUMJ); 1 $\widehat{\lambda}, 2$ 우, Nantou, Tatachia, 27 Apr. 2010, leg. C.-F. Lee (TARI); 4 우, Nantou, Tungpu, 25 to 29 Sept. 1980, leg. L.Y. Chou and T. Lin (TARI); 3 ふึત,, 12 우, same locality, 28 Apr. to 2 May 1981, leg. T. Lin and C.J. Lee (TARI); 2 우, same locality, 19 to 23 July 1982, leg. L.Y. Chou and T. Lin (TARI); 10 , Pingtung, Lilungshan, 30 Mar. 2010, leg. J.-C. Chen (TARI); 3 우, Pingtung, Wutai, 12 Apr. 2009, leg. Uika Ong (TARI); 8 ふぇે, 3 q , same but with " 27. III.2010" (JBBC, TARI); 1 \%, Taichung, Anmashan (= Tashueshan), 6 to 9 July 1979, leg. L.Y. Chou (TARI); 1 ㅇ, same locality, 3 July 2005, leg. S-T. Hisamatsu (EUMJ); 1 ๙ิ, 1 क, same locality, 21 Apr. 2010, leg. C.-F. Lee (TARI); 11 ふ઼, 4 우, same but with "24.IV.2012" (TARI, RBNN); 1 q, Taichung, Wushihkeng, 13 July 2008, leg. C.-F. Lee (TARI); 1 + , Taitung, Motien, 5 Oct. 2010, leg. C.-F. Lee (TARI); 1 q, same but with "23.V.2011” (TARI); 11

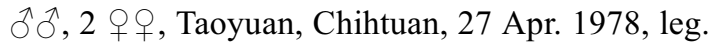
N. Yashiro (EUMJ); 1 \%, Taoyuan, Baling, 2. Aug. 1970, leg. B. S. Chang (NMNS); 2 $\widehat{\partial}, 1$ q, same locality, 19 Apr. 2009, leg. M.-H. Tsou (TARI); 1 , Taoyuan, Runghua, 14 Apr. 1972, leg. B.S. Chang (NMNS); 1 , Taoyuan, Sulo, 28 Apr. 1978, leg. N. Yashior (EUMJ).

\section{Description}

Head, prothorax, mesothoracic ventrites, and legs yellowish-brown; dorsal sides of tibiae and tarsi darkened; antenna black except for three dark-brown basal antennomeres; and metallic-blue scutellum, elytra, metathoracic ventrites, and abdomen (Figure 1). Head smooth and impunctate. Pronotum transverse, about 1.4 times wider than long, disc convex, with scattered minute punctures; lateral margins arcuate; anterior margin medially slightly concave and posterior margin sinuate. Elytra 1.5 times longer than wide, moderately convex at side and widest behind middle, broadly rounded apically, disc with irregular, minute, scattered punctures, interstices of punctures wider than diameter of each puncture.

\section{Male}

Length 5.5 to $7.7 \mathrm{~mm}$ and width 2.7 to $3.7 \mathrm{~mm}$. Antenna (Figure 2) long, reaching apical one third of elytron, filiform, three apical antennomeres laterally widened and ventrally flattened; ratio of length of antennomeres III to XI about 1.0:1.5:1.5:1.5:1.5:1.5:1.6:1.5:2.0; ratio of length to width of antennomeres III to XI about 2.7:3.5:3.4:3.4:3.2: 3.2:2.8:2.5:3.6. All tarsomeres of same width. Interstices between elytral punctures smooth. Apical margin of last 

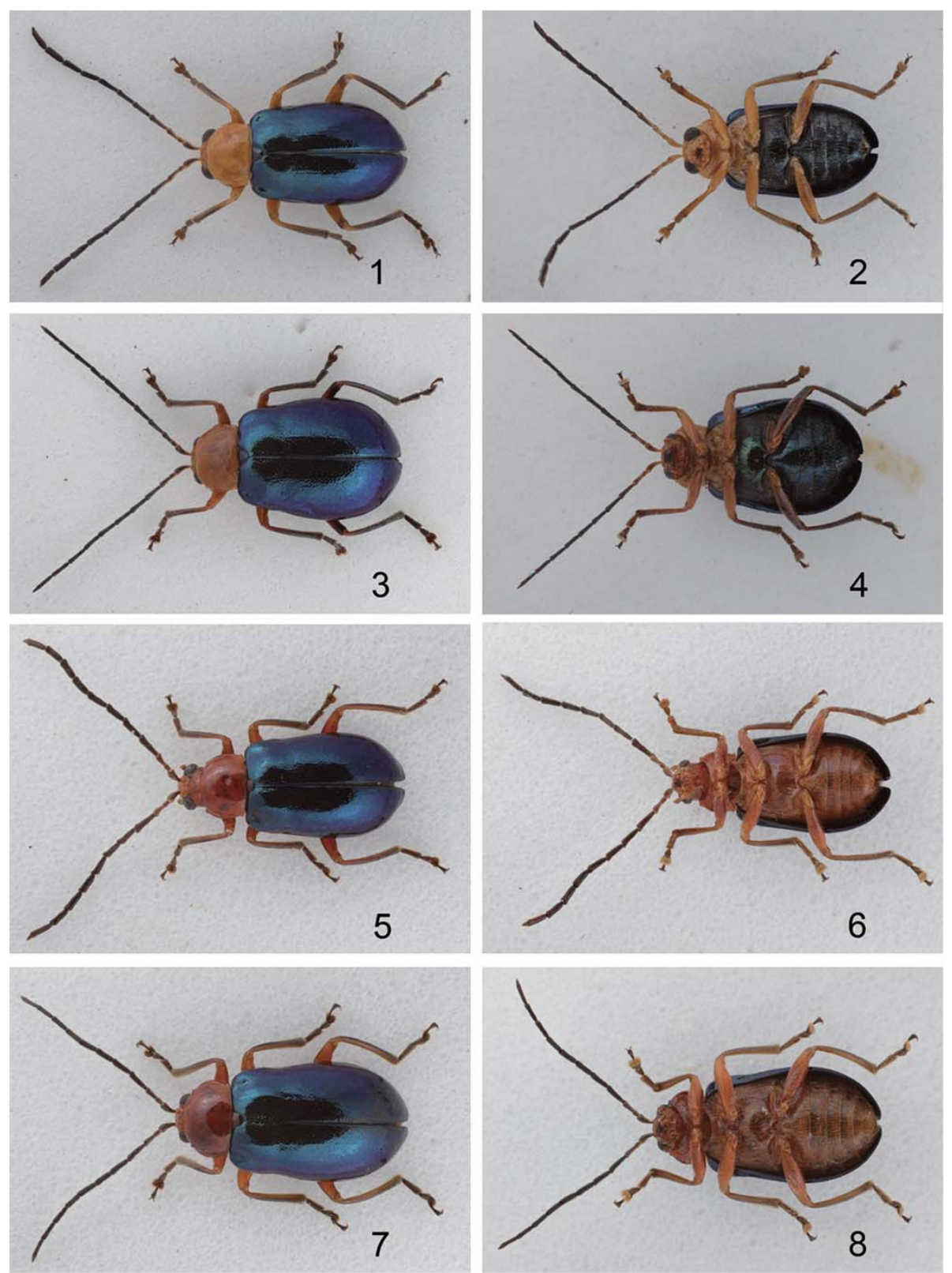

Figure 1 Habitus of species of Cneorane. (1,2) C. elegans, male, (1) dorsal and (2) ventral views; $(3,4)$ C. elegans, female, (3) dorsal and (4) ventral views; $(\mathbf{5 , 6}$ C. violaceipennis, male, (5) dorsal and (6) ventral views; $(\mathbf{7}, \mathbf{8})$ C. violaceipennis, female, (7) dorsal and (8) ventral views.

ventrite tri-lobed. Aedeagus (Figure 2) parallel-sided, about 3.8 times longer than wide, apically tapering, apex pointed; tectum long, almost reaching apex of penis, subapically wider than penis; apical margin medially bifurcate; and moderately curved and wide in lateral view (Figure 2), apex recurved.

\section{Female}

Length 7.2 to $8.5 \mathrm{~mm}$, width 4.1 to $4.6 \mathrm{~mm}$. Antenna (Figure 2) long, reaching apical one third of the elytron, filiform, ratio of length of antennomeres III to XI about
1.0:1.8:1.7:1.6:1.7:1.6:1.7:1.7:2.2; ratio of length to width of antennomeres III to XI about 2.6:4.1:3.8:4.1:4.1:4.1: 4.0:4.4:6.4. First tarsomeres of all legs same width. Interstices between elytral punctures smooth. Apical margin of the last ventrite rounded. Sternite VIII (Figure 2) well-sclerotized; apex truncate; disc with dense, long setae; denser setae along margin; and spiculum extremely long. Spermathecal receptaculum (Figure 2) strongly swollen, pump and receptaculum well separated by one layer of membrane, pump narrow and strongly curved, spermathecal duct sinuate, deeply projecting into 


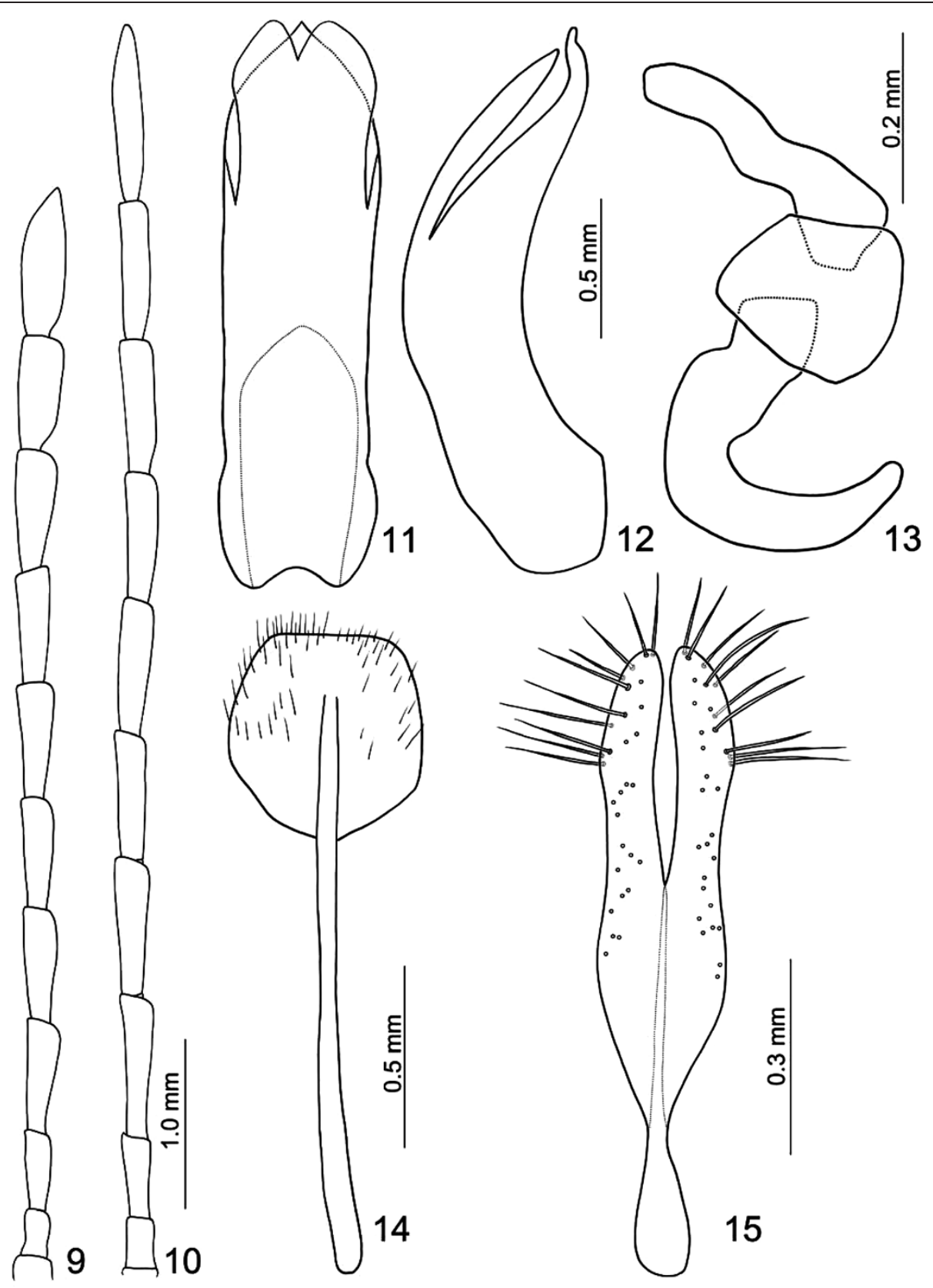

Figure 2 Cneorane elegans. (9) Antenna, male; (10) antenna, female; (11) aedeagus, dorsal view; (12) aedeagus, larval view; (13) spermatheca; (14) sternite VIII; (15) gonocoxae.

receptaculum. Gonocoxae (Figure 2) combined from base to middle, slender, about 4.5 times longer than wide, extremely narrow at basal one fourth, apex with 10 long setae.

\section{Variations}

The body size is quite variable probably due to differences in nutritional value of food. Several very small individuals on the same host plant are found during the present study; however, some normal ones are seen on nearby plants. In addition, the color of the legs are variable between different geographic populations.

\section{Remarks}

C. cyanipennis Chûjô 1938 was synonymized with C. violaceipennis (misidentified) by Kimoto (1969). However, Medvedev (2011) treated it as a distinct species based on an examination of two males. He indicated that C. cyanipennis has black legs but with red pro- and mesofemora, a smaller body size, and different form of the 
aedeagus. Actually, C. cyanipennis proved to be a junior synonym of $C$. elegans Baly 1874 with variable size and color of the legs based on an examination of several hundred specimens from various areas.

\section{Host plants}

The species thrive in plants under the Fabaceae family: Lespedeza bicolor Turcz. f. acutifolia Matsum. (Chûjô 1940), L. formosa (Vogel) Koehne (present study), Desmodium sequax Wall. (Figure 3; present study).

\section{Biological notes}

Larvae only feed on flowers and beans of the host plant (Figure 3) during autumn. It is supposed that the life history of C. elegans is similar to that of C. rugulipennis.

\section{Distribution}

C. elegans species is distributed in China (Anhui, Fujian, Gansu, Guangdong, Guanxi, Hebei, Hubei, Hunan, Heilongiiang, Jiangsu, Jiangxi, Jilin, Liaoning, Shanxi, Shaanxi, Sichuan, Zhejiang), Japan, North Korea, South
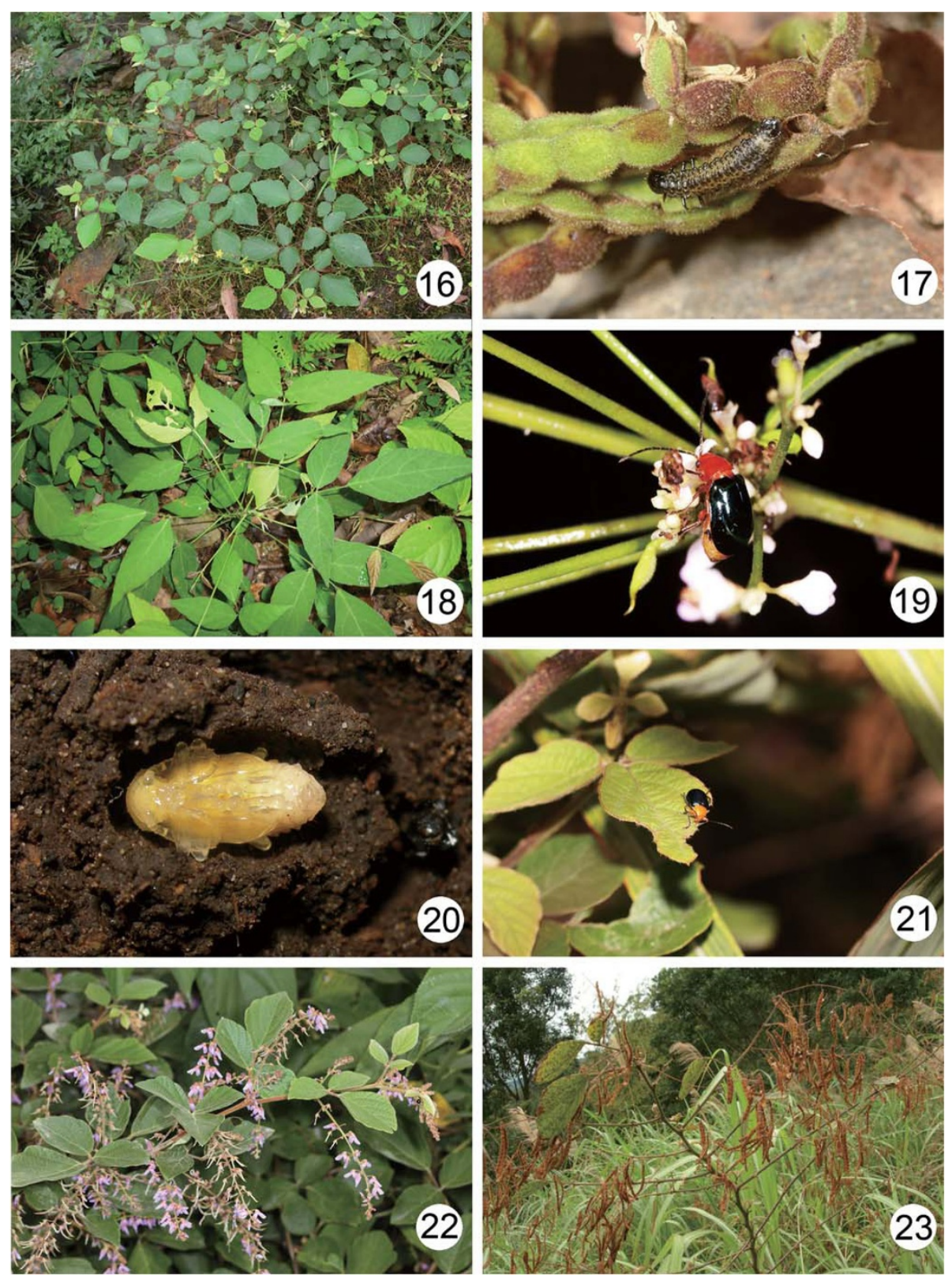

Figure 3 Field observations. (16) Desmodium sequax Wall., the host plant for Cneorane elegans and C. rugulipennis; (17) young larva of C. elegans feeding on beans inside pods of D. sequax; (18) Hylodesmum podocarpum subsp. oxyphyllum Ohashi \& Mill, the host plant for C. violaceipennis; (19) a female of $C$. violaceipennis feeding on flowers of H. podocarpum subsp. oxyphyllum; (20) a pupa of C. elegans; (21) adult of $C$. elegans feeding on leaves of D. sequax; (22) D. sequax blooming during autumn; (23) beans desiccated 1 month after blooming. 
Korea, Russia, and Taiwan. It is a widespread species and inhabits lowlands in Taiwan (Figure 4).

\section{Cneorane violaceipennis Allard 1889}

The following names are synonymies of Cneorane violaceipennis Allard 1889:

- Cneorane violaceipennis Allard 1889: 70 (China); Ogloblin 1936: 214 (China: Jiangsu, Zhejiang, Sichuan).

- Cneorane fokiensis Weise 1922: 71 (China: Fujian); Gressitt and Kimoto 1963: 550 (China: Jiangsu, Fujian, Hubei, Guizhou, Sichuan, Xizang); Yu et al. 1996: 154 (China); Wang et al. 1998: 97 (China: Fujian). syn. nov.

\section{Type material}

The following are the type materials for every species:

- Cneorane violaceipennis - Lectotype $\delta(\mathrm{MNHN})$, here designated, labeled: "Chine bor./SYNTYPE (red label)/EX MUSAEO E. ALLARD/MUSÉUM PARIS 1952 coll. R OBERTHÜR". Paralectotype: 1 , same data as for lectotype.

- Cneorane fokiensis - Holotype ô (NHRS), labeled: "Prov. Fo-Kien (China). G. Siemssen vend/fokiensis m/Typus (red label)/NHRS-JLKB 000020339”.

\section{Material examined}

The specimens examined $(n=22)$ in different areas are listed below:

- China: 1 ô, Fujian, Chungah, Tsilichiao, 1,000 m, 8 June 1942, leg. T. Maa (KMNH); 1 đ̂, Fujian,
Shaowu, Taochulan, 1,000 m, 1 May 1942, leg. T. Maa (KMNH); 1 ठ, same but with "21.V.1942" $(\mathrm{KMNH}) ; 2$ 우, Hubei, Lichuan Distr., Suisapa, 1,000 m, 24 Aug. 1948, leg. Gressitt and Djou (KMNH).

- Taiwan: 1 + , Taipei, Wulai-Fushan, 27 Mar. 2007, leg. S.-F. Yu (TARI); 2 ô, 2 우오, same locality, 30 Apr. 2008, leg. H.-J. Chen (TARI, JBBC); 1 त, same but with "10.IV.2010" (TARI); 1 §, 2 우, same locality, 18 Apr. 2010, leg. M.-H. Tsou (TARI); 1 9, same but with "7.VIII.2010" (TARI); 1 ㅇ, same but with "7.X.2011" (TARI); 1 ㅇ, Taipei, Tsaoshan (= Yangmingshan), 10 May 1963, leg. S. C. Chiu (TARI); 1 ㅇ, Nantou, Hoshe, 22 July 1982, leg. L.Y. Chou and T. Lin (TARI); 1 o, 1 क, Nantou, Tungpu, 28 Apr. to 2 May 1981, leg. T. Lin and C.J. Lee (TARI); 1 q, same locality, 19 to 23 July 1982, leg. L.Y. Chou and T. Lin (TARI); 1 , same locality, 23 to 27 July 1984, leg. K.C. Chou and C.H. Yang (TARI).

\section{Description}

General color reddish-brown, antenna black but three basal antennomeres dark-brown; tarsi and ventral side of tibia darkened; and elytron metallic-blue (Figure 1). Head smooth and impunctate. Pronotum transverse, about 1.5 to 1.6 times wider than long, disc convex, with scattered minute punctures; lateral margins arcuate; anterior margin medially and slightly concave, and posterior margin sinuate. Elytra 1.5 times longer than wide, moderately convex at side and widest behind middle, broadly rounded apically, disc with irregular, minute, scattered punctures,

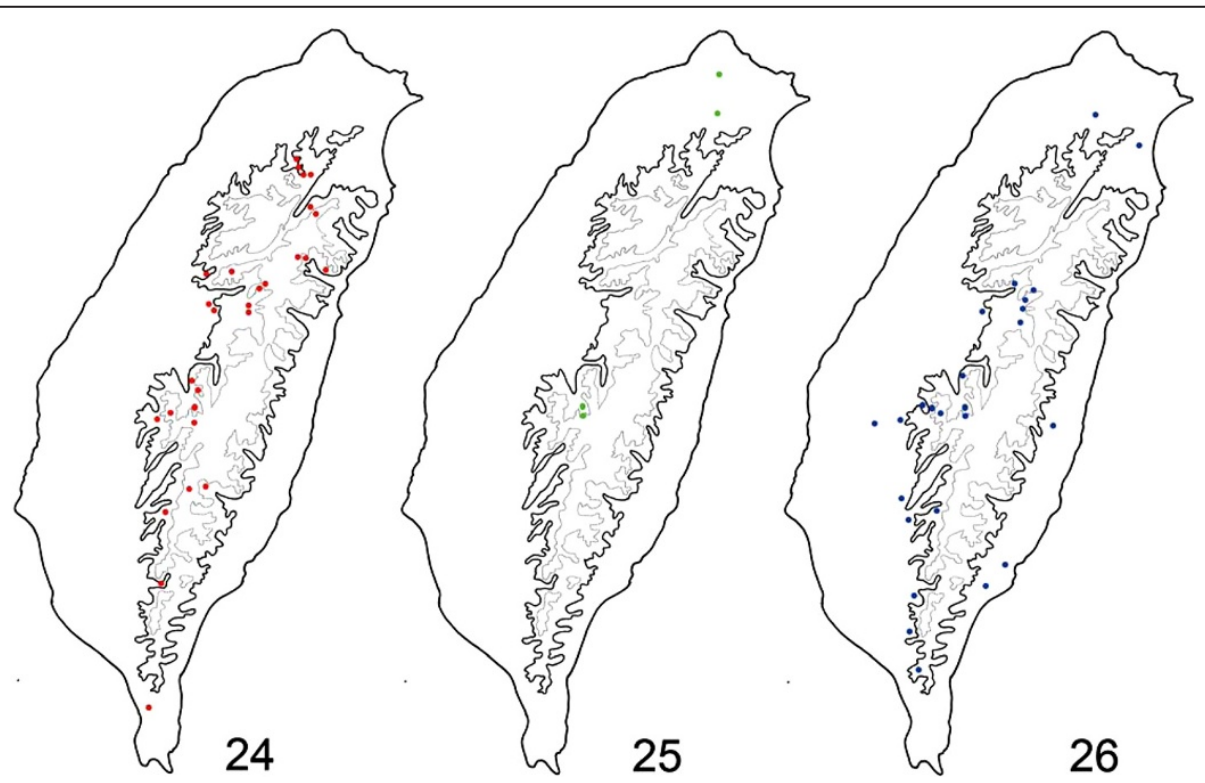

Figure 4 Distribution map of Cneorane species, black line: 1,000 m; gray line: $2,000 \mathrm{~m}$ in elevation. (24) C. elegans; (25) C. violaceipennis; (26) C. rugulipennis. 
interstices of punctures wider than diameter of each puncture.

\section{Male}

Length 7.5 to $8.5 \mathrm{~mm}$, width 3.5 to $5.2 \mathrm{~mm}$. Antenna (Figure 5) long, reaching apical one third of elytron, filiform, apically widened, four apical antennomeres strongly widened, ratio of length of antennomeres III to XI about 1.0:1.9:1.8:1.8:1.9:1.9:1.8:1.8:2.4; ratio of length to width of antennomeres III to XI about 1.8:4.2:3.7:3.7: 3.9:3.1:3.0:2.9:4.7. First tarsomeres of all legs having same width. Interstices between elytral punctures smooth. Apical margin of last ventrite tri-lobed. Aedeagus (Figure 5) parallel-sided, about 3.9 times longer than wide, apex pointed; tectum short, much lower than apex of penis, apically much narrower than penis, apical margin medially bifurcate; and weakly curved and extremely narrow in lateral view (Figure 5), apex straight.
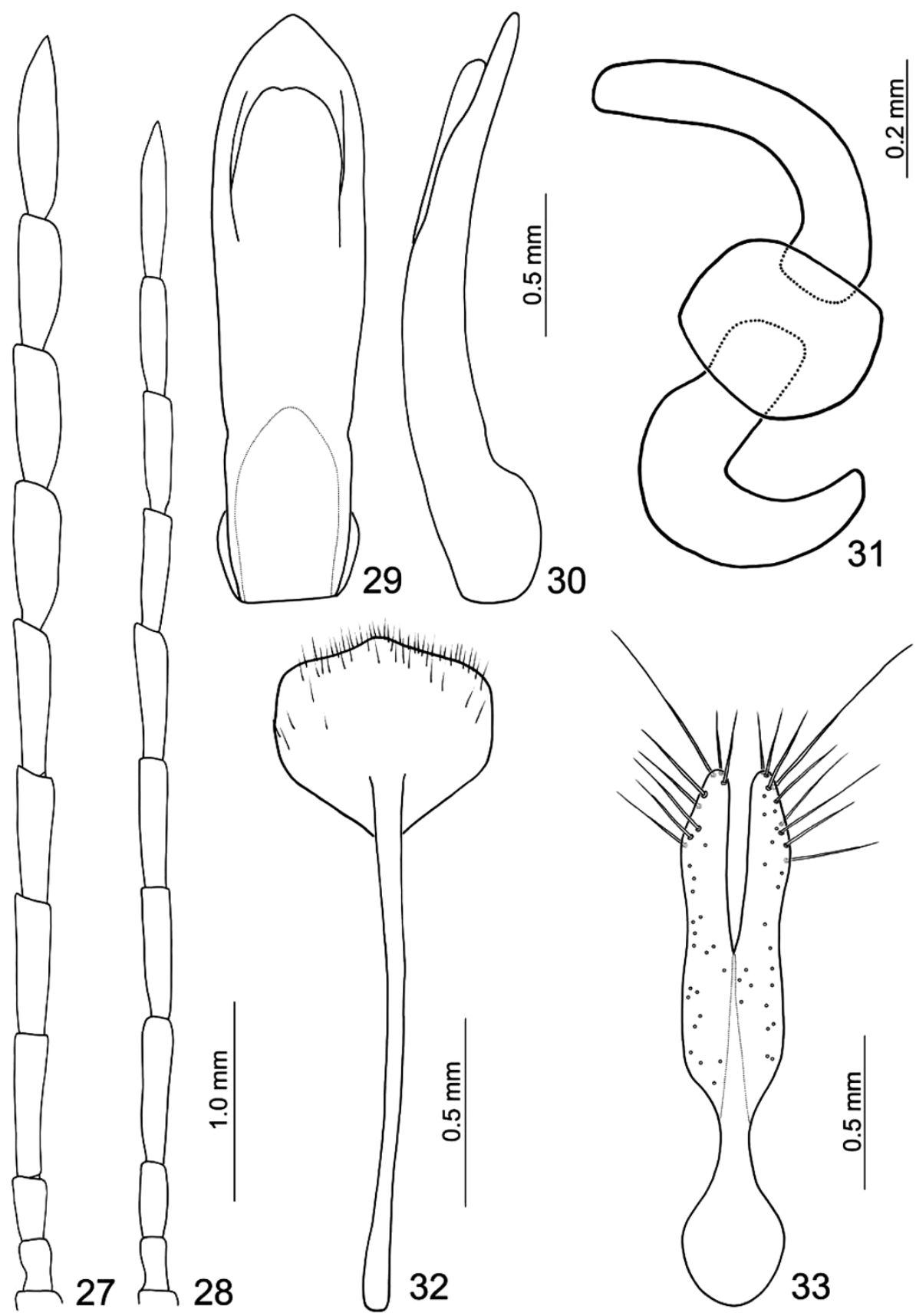

Figure 5 Cneorane violaceipennis. (27) Antenna, male; (28) antenna, female; (29) aedeagus, dorsal view; (30) aedeagus, lateral view; (31) spermatheca; (32) sternite VIII; (33) gonocoxae. 


\section{Female}

Length of the female 7.3 to $8.1 \mathrm{~mm}$, width 3.8 to $4.1 \mathrm{~mm}$. Antenna (Figure 5) long, reaching apical one third of elytron, filiform, ratio of length of antennomeres III to XI about 1.0:2.0:1.8:1.7:1.7:1.6:1.6:1.6:2.1; ratio of length to width of antennomeres III to XI about 2.6:4.9:4.3:4.5:4.2: 4.3:4.3:4.6:7.1. First tarsomeres of all legs with same width. Interstices between elytral punctures smooth. Apical margin of last ventrite rounded. Sternite VIII (Figure 5) well sclerotized, apex convex at middle, disc with dense setae along margin, spiculum extremely long. Spermathecal receptaculum (Figure 5) strongly swollen, pump and receptaculum well separated by one layer of membrane, pump small, narrow, strongly curved, spermathecal duct curved, deeply projecting into receptaculum. Gonocoxae (Figure 5) combined from base to middle, slender, about 4.8 times longer than wide, abruptly narrowed at basal one fourth, apex with eight or nine long setae.

\section{Variations}

Variations are specimens from China with a blackishbrown abdomen.

\section{Remarks}

Medvedev (2011) indicated that only the aedeagi are diagnostic for both $C$. fokiensis (= C. violaceipennis) and C. elegans. Actually, a number of characters are reliable for distinguishing both species. C. violaceipennis differs from $C$. elegans by its reddish-brown metathoracic ventrites and scutellum (in contrast with metallic-blue ones in C. elegans) and the four apical cylindrical antennomeres in the male (in contrast with the four apical ventrally flattened ones in C. elegans).

\section{Host plants}

This species thrives in plants under the Fabaceae family: Hylodesmum podocarpum (DC.) H. Ohashi \& R.R. Mill subsp. oxyphyllum (DC.) H. Ohashi \& R.R. Mill (Figure 3; present study); and Cupressaceae: Cunninghamia sp., (this record is very doubtful; Gressitt and Kimoto 1963).

\section{Distribution}

C. violaceipennis is found in China (Fujian, Guizhou, Hubei, Hunan, Jiangsu, Shanxi, Shaanxi, Sichuan, Zhejiang) and Taiwan (new record). It is a rare species that is scattered throughout Taiwan (Figure 4).

\section{Cneorane rugulipennis Baly}

The following names are synonymies of Cneorane rugulipennis Baly:

- Cneoraus [sic!] rugulipennis Baly 1886: 27 (India).

- Cneorane rugulipennis: Weise 1924: 127 (catalog); Chûjô 1935: 163 (Taiwan); Maulik 1936: 339 (India and Myanmar); Chûjô 1962: 203 (redescription); Kimoto 1969: 35 (Taiwan); Kimoto 1989a: 251 (Taiwan).

- Cneorane delatouchii Fairmaire 1888: 45. (synonymized with C. femoralis by Jacoby 1890); synonymization needs confirmation.

- Cneorane femoralis Jacoby 1888: 350 (China); Gressitt and Kimoto 1963: 549 (China: Fujian, Guangdong, Hainan, Sichuan, Tibet); Kimoto 1965b: 488 (Taiwan); Kimoto 1966: 29 (Taiwan); Kimoto 1969: 35 (Taiwan); Kimoto 1986: 57 (Taiwan); Kimoto 1989a: 251 (Taiwan); Kimoto 1989b: 92 (Laos); Yu et al. 1996: 154 (China). syn. nov.

- Cneorane formosana Weise 1922: 72 (Taiwan); Chûjô 1935: 163 (Taiwan); Chûjô 1962: 204 (redescription); Chûjô 1963: 390 (Taiwan). Synonymized with C. femoralis by Kimoto 1965 b.

\section{Type material}

The following are the type materials for every species:

- Cneoraus rugulipennis - Lectotype $q(\mathrm{BMNH})$, here designated, labeled: "Type (circle label with red collaris)/Type (handwritten)/Ind (handwritten)/ Cneoraus rugulipennis Baly India; Trans. Ent. Soc. 1886 p. 27 "Cneoraus" misprint rugulipennis Baly (on the back)". Paralectotype: 1 ( $\mathrm{BMNH})$ : "SYNTYPE (circle label with blue collar)/Ind (handwritten)/Baly coll".

- Cneorane delatouchii - The depository of types is unknown. They were not found at the MNHN where they are most probably deposited (Antoine Mantilleri personal communication).

- Cneorane femoralis - Eleven specimens bear the label which is the same as the original paper at the MCZC. Although there is only a specimen bearing a type label among them, all should be treated as syntypes since the number of types was not indicated and the type label was not put on by the author. Lectotype $\hat{\jmath}$, here designated, labeled "Foochau, Apr., 1886. Leech./1st Jacoby Coll. Cneorane femoralis Jac./Type 18185 (red label)". Paralectotypes: 3 우, same data as for lectotypes; 5 $\widehat{\jmath} \hat{o}$, labeled "Foochau, Apr., 1886. Leech."; 1 ㅇ, labeled "Foochau, Apr., 1886. Leech./1st Jacoby Coll./Cneorane femoralis Jac.”; 1 q, labeled "Foochau, April, 1886. Leech./1st Jacoby Coll./Type 18185 (red label)/Cneorane femoralis Jac./Jan.-Jul. 2004 MCZ Image Database".

- Cneorane formosana - The depository of types is unknown. They were not found at the MNHUB or NHRS where types designated by Weise are most probably deposited. 


\section{Material examined}

The specimens examined $(n=155)$ in different areas are listed below.

- China: 2 우, Hainan, Ryosui, 28 Sept. 1942, leg. Miwa and Mitono (TARI); 1 $\hat{\text {, }} 1$ ㅇ, Hainan, Shuiman, 26 May 1960, leg. C.-C. Li (TARI); 1 q, Yunnan, Vallis flumin Soling-ho. (TARI)

- Laos: 3 우, Hua Phan Prov., Ban Saluei, Phu Phan Mt., $20^{\circ} 15^{\prime} \mathrm{N}, 104^{\circ} 02^{\prime} \mathrm{E}, 1,500$ to $2,000 \mathrm{~m}, 26$ Apr.11 May 2001, leg. J. Bezděk (JBBC)

- Nepal: 1 đ̃, 2 우, Bagmati Zone, Rasuwa Distr., Langtang Natl. Park, Dhunche-Bharkhu-Syabru, 2,000 to $2,800 \mathrm{~m}, 6$ to 15 May 1996, leg. M. Pejcha (JBBC); 1 ô, Jing-Sang-La, 3800 m, 6 to 7 May 1962, leg. G. Ebert (KMNH)

- Taiwan: 1 o, Chiayi, Arisan (=Alishan), 27 May 1917, leg. T. Shiraki (TARI); 1 q, same locality, 19 May 1927, leg. K. Fukuda (TARI); 1 +, same locality (= Jiujiro), 4 June 1939, leg. T. Mitono (TARI); 1 ふૈ, same locality, 21 Apr. 2010, leg. Uika Ong (TARI); 4 우, same but with “28.IV.2011” (TARI); 2 ふึે, 2 우, Chiayi, Karapin (= Chaoliping), 2 Apr. 1938, leg. Y. Yano (TARI); 1 +, Chiayi, Shihcho, 10 May 2011, leg. M.-H. Tsou (TARI); 2 우, Chiayi, Taihorin (= Tairin), 22 Aug., leg. H. Sauter (TARI); 1 q, same but

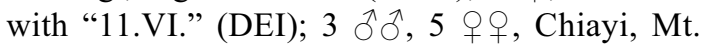
Taiko (= Takengshan), 4 to 10 Feb. 1924, leg. M. Kato (TARI); 1 q, Hualien, Mizuho (= Juisui), 23 Mar. 1935, leg. M. Chujo (TARI); 1 o, Ilan, Wufengchi, 13 Mar. 1956, leg. S.C. Chiu (TARI); 1 , Kaohsiung, Fujieda (Tengchih), 13 Mar. 1929, leg. J. Sonan (TARI); 1 ô, same locality, 4 July 2011, leg. M.-H. Tsou (TARI); 1 , Kaohsiung, Hoozan (=Fengshan), 7 Sept., leg. H. Sauter (DEI); 1 त, Kaohsiung, Kosempo (= Chiasien), leg. Sauter (NMNS); 1 q, Kaohsiung, Rokkiri (= Liukuei), 1 Sept. 1927, leg. J. Sonan and K. Shibata (TARI); 1 ô, Nantou, Lushan Spa, 10 May 1978, leg. N. Yashiro (EUMJ); 1 q, Nantou, Musha (= Wushe), 18 May to 15 June 1919 , leg. T. Okuni (TARI); 1 त, same locality, 26 Oct. 1928, leg. M. Chujo (NMNS); 1 స, 1 q, same locality, 23 Mar. 2009, leg. Uika Ong (TARI); 1 \% , Nantou, Naifunpo (= Mingte), 9 Sept. 1924, leg. T. Shiraki (TARI); 7 우, Nantou, Nanshanchi, 25 July 2008, leg. W.-T. Liu (TARI); 7 q 9 , same locality, 14 Sept. 2011, C.-L. Chiang (TARI); 1 ô, Nantou, Sungkang, 8 May 1978, leg. N. Yashiro (EUMJ); 2 우, Nantou, Tonpo (= Tungpu), 10 Apr. 1924, leg. T. Shiraki (TARI); 1 , same locality, 25 to 29 Sept. 1980, leg. L.Y. Chou and T. Lin (TARI); 1 ㅇ, same but with “19-23.VII.1982” (TARI); 9 ふ઼ડ, 6 우, 31 Jan. 1989, leg. K.W. Huang (NMNS); 2 우, Nantou, Tungfu, 13 Sept. 2011, leg. C.-F. Lee
(TARI); 1 9, Nantou, Wanfengtsun, 12 Apr. 2007, leg. W.-T. Liu (TARI); 1 q, same but with "25.IV.2008” (TARI); 1 q, Nantou, Yushih, 4 Aug. 1981, leg. T. Lin and W.S. Tang (TARI); 2 ふふَ, 1 q, Pingtung, Dahanshan, 11 to 12 Apr. 2012, leg. J. Yamasako (EUMJ); 1 ㅇ, Pingtung, Raisha (= Laiyi), 30 Aug. 1927, leg. J. Sonan (TARI); 1 त, 1 q, Pingtung, Supaiwan, 20 Mar. 1927, leg. S. Issiki (TARI); 1 , Taichung, Chiapaotai, 14 to 18 Oct. 1980, leg. K.S. Lin and C.H. Wang (TARI); 1 , Taipei, Rimogan (=Wulai-Fushan), 24 Sept. 1938, leg. Y. Miwa (TARI); 1 đ, 1 q, same locality, 6 Apr. 2008, leg. Y.-L. Lin (TARI); 14 우, same locality, 13 Oct. 2008, leg. H.-J. Chen (TARI); 13 우, same but with "18.X.2008" (TARI); 1 \%, same but with "1. XI.2008" (TARI); 1 q, same but with "19.II.2009"

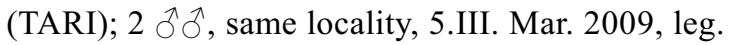
Y.-L. Lin (TARI); 1 đ, same locality, 12 Mar. 2009,

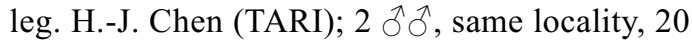
Mar. 2010, leg. Y.-T. Wang (TARI); 19 $\widehat{\jmath}, 13$ 우우, same locality, 30 Mar. 2012, leg. T.-H. Lee (TARI, JBBC, DEI); 2 ふึ, 3 우, Taitung, Rikiriki (= Lichi), 20 Mar. 1924, leg. T. Takeda (TARI); 1 q, same but with "21.III.1924" (TARI); 1 \%, Taitung, Taito (= Pilan), 7 Mar. 1914, leg. I. Nitobe (TARI); 2 ồ, same locality, 25 Feb. to 27 Mar. 1919, leg. S. Inamura (TARI).

\section{Description}

Head, prothorax, mesothoracic ventrites yellowish-brown; legs dark brown or black, but front and middle coxae and femora, and ventral side of front tibia yellowish-brown; antenna black except yellowish-brown ventral sides of three basal antennomeres; and scutellum, elytra, metathoracic ventrites, and abdomen metallic blue or green (Figure 6). Head smooth and impunctate. Pronotum transverse, about 1.3 to 1.4 times wider than long, disc convex, with scattered minute punctures; lateral margins arcuate; anterior margin medially and slightly concave, posterior margin sinuate. Elytra 1.7 times longer than wide, moderately convex at side and widest behind middle, broadly rounded apically, disc with random, impressed, dense punctures, interstices between punctures narrower than diameter of each puncture.

\section{Male}

Length of the male 6.7 to $10.2 \mathrm{~mm}$, width 3.2 to $4.5 \mathrm{~mm}$. Antenna (Figure 7) long, reaching apical one third of elytron, filiform, ratio of length of antennomeres III to XI about 1.0:1.3:1.2:1.2:1.2:1.1:1.1:1.1:1.3; ratio of length to width of antennomeres III to XI about 3.1:3.9:3.8:3.8: 3.8:3.9:3.9:4.2:5.8. Front and middle tarsomeres I widened (Figure 8). Interstices between elytral punctures smooth. Apical margin of last ventrite tri-lobed. Aedeagus (Figure 7) parallel sided, about 4.1 times longer than wide, apex 

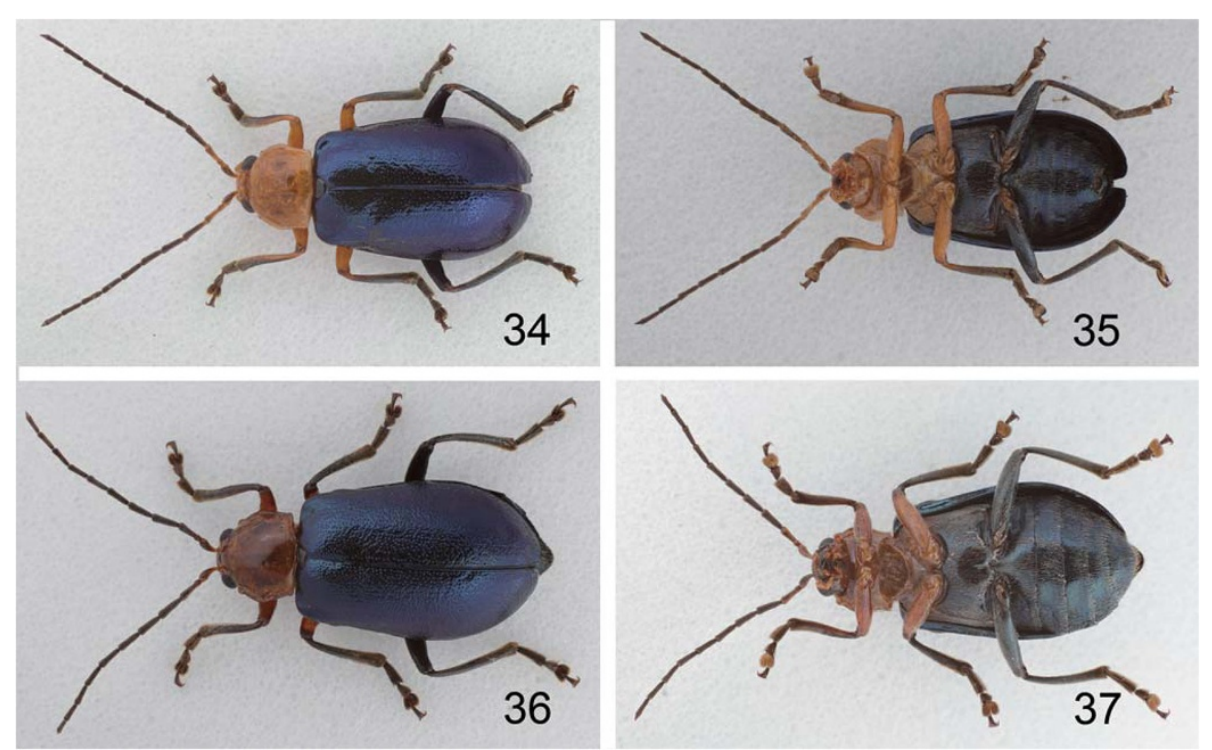

Figure 6 Habitus of Cneorane rugulipennis. (34) Male, dorsal view; (35)

5) male, ventral view; (36) female, dorsal view; (37) female, ventral view.

rounded, straight in lateral view; tectum short, much lower than apex of penis, apically a little wider than penis, apical margin medially bifurcate; moderately curved and wide in lateral view (Figure 7).

\section{Female}

Length 7.8 to $10.8 \mathrm{~mm}$, width 3.5 to $5.2 \mathrm{~mm}$. Antenna (Figure 7) long, reaching apical one third of elytron, filiform, ratio of length of antennomeres III to XI about 1.0:1.5:1.4:1.3:1.3:1.3:1.3:1.2:1.5; ratio of length to width of antennomeres III to XI about 3.2:4.2:4.2:4.0:4.1:4.0:4.0: 3.9:5.5. All tarsomeres with same width (Figure 8). Interstices between elytral punctures shagreened. Apical margin of last ventrite rounded. Sternite VIII (Figure 7) well-sclerotized, apex truncate, disc with dense, long setae, denser setae along margin, spiculum extremely long, basally widened. Spermathecal receptaculum (Figure 7) strongly swollen, pump and receptaculum well separated by one layer of membrane, pump narrow and strongly curved, spermathecal duct curved, widened near base, deeply projecting into receptaculum. Gonocoxae (Figure 7) combined from base to middle, stout, about 3.9 times longer than wide, narrowest at basal one fourth, apex with nine long setae.

\section{Variations}

Specimens from Nepal and Laos lack a groove near the posterior angles of the pronotum. This character appears in Taiwanese and Chinese specimens (Medvedev 2011).

\section{Remarks}

Most specimens from Taiwan were identified as $C$. formosana or C. femoralis. Some individuals with metallic green color were identified as C. rugulipennis by Chûjô (1935). Males with smooth interstices between elytral punctures were identified as C. rugulipennis by Kimoto (1969, 1989a). Although the color of the elytra is variable, this species has unique sexually dimorphic characters, including smooth interstices between elytral punctures and widened front and middle tarsomeres I in males, in contrast with the shagreened interstices between elytral punctures and normal front and middle tarsomeres I in females.

\section{Host plant}

This species thrive in plants under the Fabaceae family: Desmodium sequax Wall. (present study).

\section{Biological notes}

The life history is univoltine based on field observations. Females deposit eggs at the base of flower buds of the host plant, D. sequax in autumn. The eggs hatch in 10 to 15 days. The hatched larvae feed on the flowers. Older larvae prefer to feed on beans inside of the pods. The larval stage lasts about 2 months. Mature larvae leave the host plant and crawl down to the soil. They build chambers underground for pupation. The pupal stage (Figure 3) lasts about 20 days. Newly emerged adults do not crawl out of the ground until spring. Adults feed on leaves (Figure 3) and survive from spring to autumn. They may disappear during the summer most probably due to summer diapause.

\section{Distribution}

This species is found in China (Fujian, Guangdong, Guizhou, Hainan, Hubei, Hunan, Sichuan, Tibet, Yunnan), 


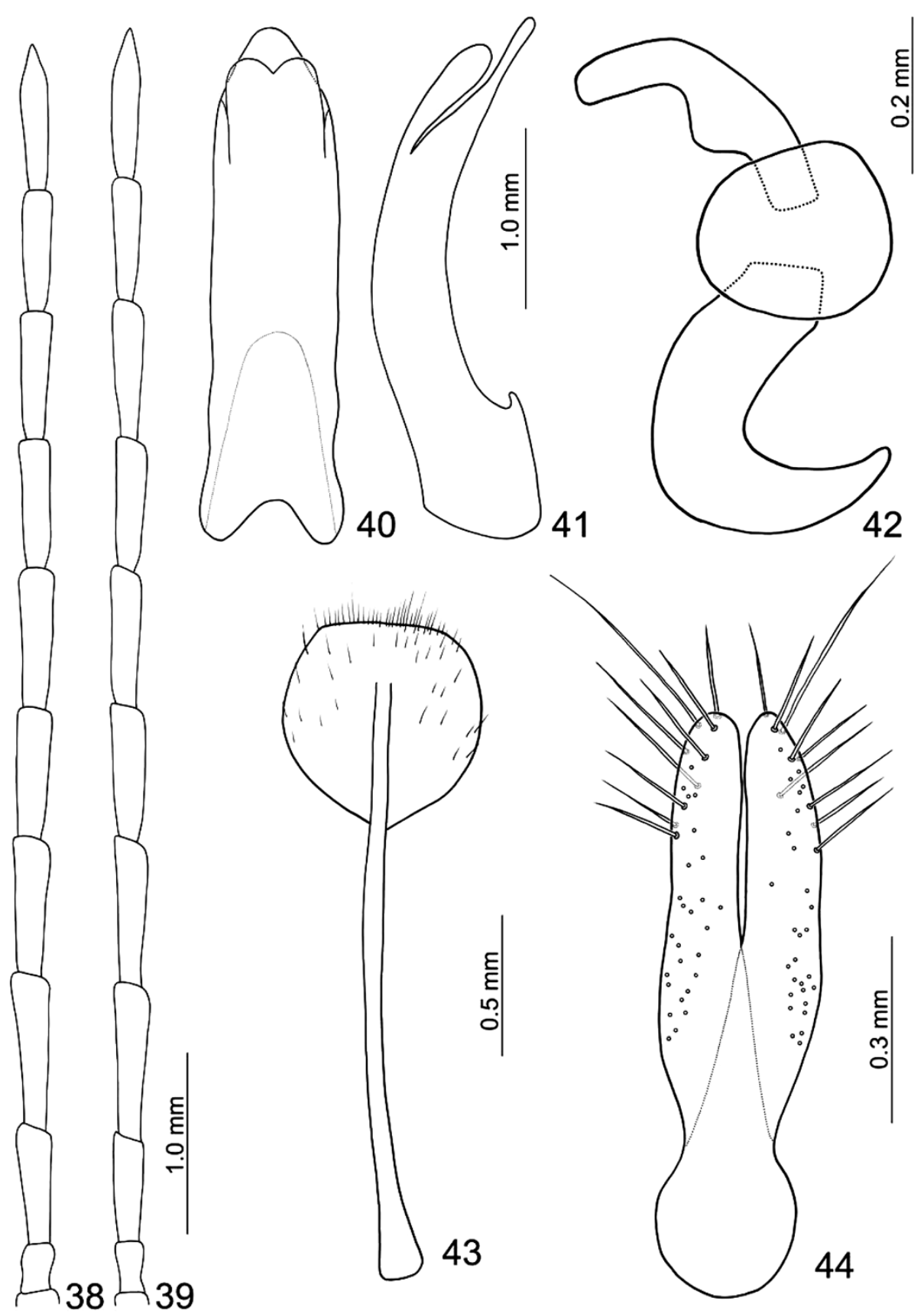

Figure 7 Cneorane rugulipennis. (38) Antenna, male; (39). antenna, female; (40) aedeagus, dorsal view; (41) aedeagus, lateral view; (42) spermatheca; (43) sternite VIII; (44) gonocoxae.

India, Laos, Myanmar, Nepal, Taiwan. It is a widespread species and inhabits mountainous areas in Taiwan.

\section{Key to the species of Cneorane from Taiwan}

1. Interstices between elytral punctures wider than diameter of each puncture and smooth in both sexes; all tarsomeres same width; three or four apical antennomeres widened in males

(Figures 2 and 5)..... 2

- Interstices between elytral punctures narrower than diameter of punctures, interstices smooth in males and shagreened in females, front and middle tarsomeres I widened in males (Figure 8); antenna filiform in both sexes (Figure 7)...C. rugulipennis Baly 


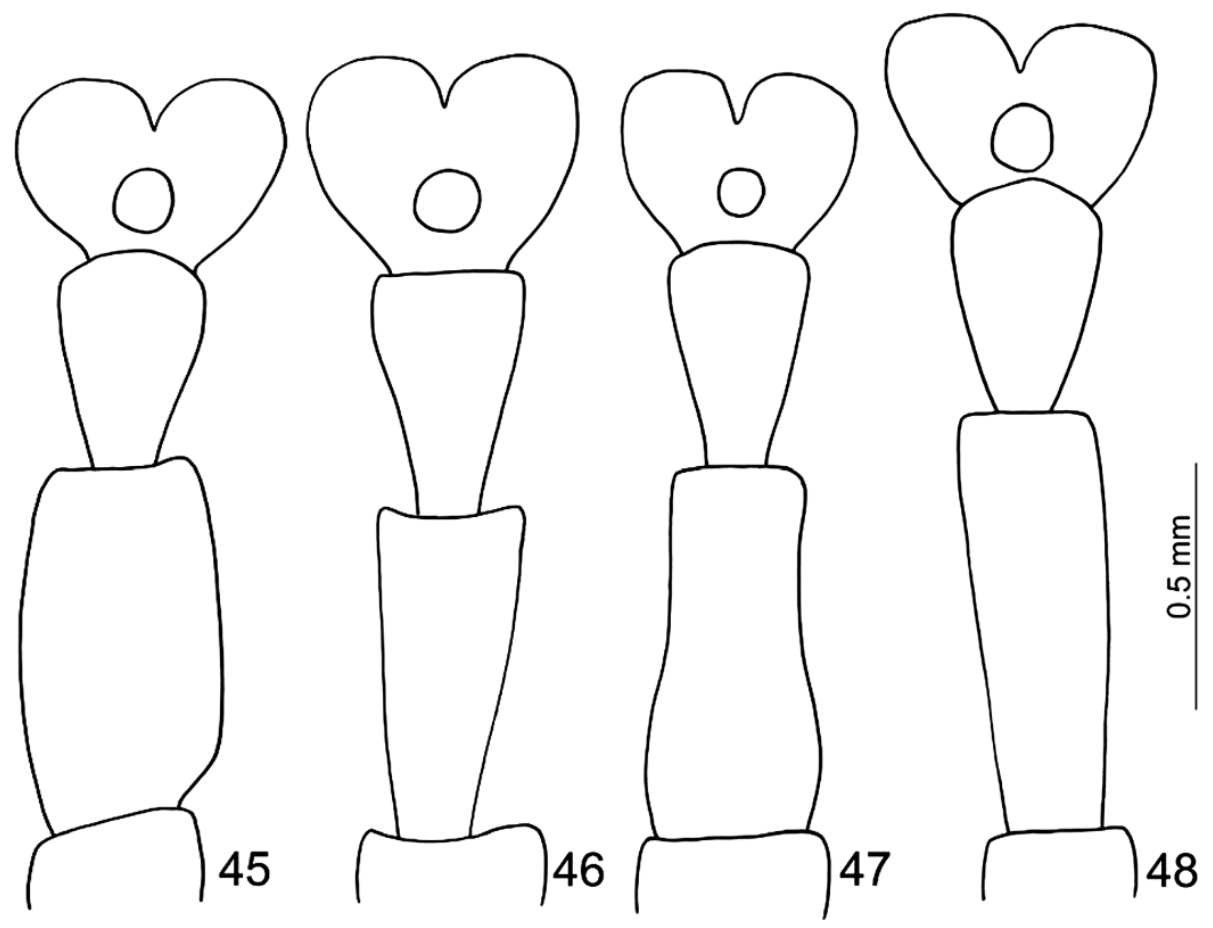

Figure 8 Cneorane rugulipennis. (45) Front tarsus, male; (46) front tarsus, female; (47) middle tarsus, male; (48) middle tarsus, female.

2. Metathoracic ventrites and scutellum reddishbrown (Figure 1), apical antennomeres widened and cylindrical in males C. violaceipennis Allard Metathoracic ventrites and scutellum metallic blue (Figure 1), apical antennomeres widened and ventrally flattened in males C. elegans Baly

\section{Conclusions}

Although Zaitzev and Dap (1982) found larvae of $C$. intermedia Fairmaire, 1889 between layers of leaves of host plants, the feeding behavior was not observed. Laboratory rearing indicated that larvae of $C$. rugulipennis only feed on flowers and beans inside pods of $D$. sequax. This result may imply that limitation of larval food could affect the life history of Cneorane species. The host plant, $D$. sequax, only blooms (Figure 3 ) during autumn. Females lay eggs on flower buds at that period of time. Larvae spend 2 months developing. Mature larvae crawl underground for pupation during winter. Newly emerged adults emerge from the ground and feed on young leaves in spring. Females survive until autumn to deposit eggs; while on the other hand, males may die 2 or 3 months after emergence. This could explain why only females are collected in autumn as shown by historic collections.

Because beans mature and desiccate in a short period of time (about 1 month; Figure 3), larval food sources are often temporary. Very small adults resulting from insufficient food can be found in the field. The body size is variable for some species of Cneorane. In addition to body size, some characters are also variable as shown by examination of extensive collections from various areas, such as the color of tibiae and tarsi in C. elegans, the color of the abdomen in C. violaceipennis, and the color of the elytra in C. rugulipennis. In contrast, some characters are reliable for diagnosis, including the color of the scutellum and the metathoracic ventrites for C. elegans and $C$. violaceipennis. In addition, each species has unique sexually dimorphic characters, including smooth interstices between elytral punctures and widened first tarsomeres of the front and middle legs in males of C. rugulipennis, widened and ventral flattened apical antennomeres in males of C. elegans, and widened and cylindrical apical antennomeres in males of $C$. violaceipennis. The present state of taxonomic study on this genus is insufficient. However, it can be improved if variable characters are detected and sexually dimorphic characters are found by examining sufficient material. The key provided by Medvedev (2011) needs a lot of modification since a number of variable characters are included.

\section{Competing interests}

The authors declare that they have no competing interests.

\section{Authors' contributions}

CFL was responsible for species descriptions and examination of material. JB collected cited literature and directed the study. All authors read and approved the final manuscript. 


\section{Acknowledgements}

We would like to thank all curators listed above for giving us the opportunity to study the material in their collections. We thank the Taiwan Chrysomelid Research Team for the assistance in collecting material, including Ms. S.F. Yu, Mr. M.H. Tsao, Mr. W.T. Liu, Mr. H.J. Chen, Mr. J.C. Chen, Mr. T.H. Lee, and Ms. H. Lee. We especially thank Mr. M.H. Tsao, Mr. H.J. Chen, Mr. T.H. Lee, and Ms. H. Lee for photos of host plants and live larvae, pupae, and adults of Cneorane species, Mr. T.H. Lee for photos of dorsal and ventral habitus of each species, and Dr. M. Bai (Institute of Zoology, Chinese Academy of Sciences, Beijing, China) for the gift of specimens of C. elegans and C. rugulipennis.

\section{Author details}

${ }^{1}$ Applied Zoology Division, Taiwan Agricultural Research Institute, 189 Chung-Cheng Road, Taichung 413, Wufeng, Taiwan. ${ }^{2}$ Department of Zoology, Mendel University, Zemědĕlská 1, Brno 613 00, Czech Republic.

Received: 3 October 2012 Accepted: 7 February 2013

Published: 10 September 2013

\section{References}

Allard E (1889) Note sur les galérucides, coléoptères phytophages. Bull ComptesRendus des Séances de las Soiété Entomol Belg 1889:66-87

Baly JS (1865) Descriptions of new genera and species of Gallerucidae. Entomol Month Mag 2:97-101

Baly JS (1874) Catalogue of the phytophagous coleoptera of Japan, with descriptions of the species new to science. Trans Entomol Soc Lond 1874:161-217

Baly JS (1886) Descriptions of new genera and species of galerucidae. Trans Entomol Soc Lond 1886:27-39

Baly JS (1890) Descriptions of two new genera, and of some uncharacterized species of galerucinae. Entomol Month Mag 26:12-14

Chûjô M (1935) H. Sauter's formosa-ausbeute: subfamily galerucinae (coleoptera: chrysomelidae). Arbeiten über Morphologische und Taxonomische Entomologie 2:160-174

Chûjô M (1938) H. Sauter's formosa-collection: subfamily galerucinae (coleoptera: chrysomelidae). Arbeiten über Morphologische und Taxonomische Entomologie 5:135-152

Chûjô M (1940) Beitrag zur chrysomeliden-fauna der insel Sikoku (Japan) II. Kontyû 14:106-125

Chûjô M (1941a) Chrysomelid-beetles from Korea (IV). Trans Nat Hist Soc Formosa 31:155-174

Chûjô M (1941b) First supplement to the fauna of Korean chrysomelid-beetles (I). Trans Nat Hist Soc Formosa 31:451-462

Chûjô M (1962) A taxonomic study of the chrysomelidae (insecta: coleoptera) from Formosa part XI. Subfamily galerucinae. Phil J Sci 91:1-239

Chûjô M (1963) Chrysomelid-beetles from Formosa, preserved in the Hungarian history museum. Budapest Ann Hist Nat Mus Hung 65:379-402

Chûjô M (1965) Chrysomelid-beetles of Formosa (I). Spec Bull Lepidopt Soc Jpn 1:88-104

Chûjô M, Kimoto S (1961) Systematic catalog of Japanese chrysomelidae (coleoptera). Pac Insects 3:117-202

Fairmaire L (1887) Notes sur les coléoptères environs de pékin ( $1^{\text {re }}$ partie). Rev d'Entomol 6:312-335

Fairmaire L (1888) Coléoptères l'intérieur de la Chine. Ann Soc Entomol Belg $32: 7-46$

Fairmaire L (1889) Coléoptères l'intérieur de la chine. Ann Soc Entomol Fran 6:5-84

Gressitt JL, Kimoto S (1963) The chrysomelidae (coleopt.) of China and Korea. Pac. Insects Monogr 1B:301-1026

Heyden LFJD (1887) Verzeichniss der von herrn Otto herz auf der chinesischen halbinsel Korea gesammelten coleopteren. Horae Soc Entomol Ross 21:243-273

Jacoby M (1888) Descriptions of new species of phytophagous coleoptera from Kiukang (China). Proc Zool Soc Lond 1888:339-351

Jacoby M (1890) Descriptions of new species of phytophagous coleoptera received by Mr. J. H. Leech, from Chang-yang, China. Entomologist 23:193-197

Kimoto S (1965a) The chrysomelidae of Japan and the Ryukyu islands. VII. Subfamily galerucinae II. J Fac Agric Kyushu Univ 13:369-400
Kimoto S (1965b) A list of specimens of chrysomelidae from Taiwan preserved in the naturhistorisches museum Wien (insecta: coleoptera). Ann Naturhist Mus Wien 68:485-490

Kimoto S (1966) A list of the chrysomelid specimens of Taiwan preserved in the zoological museum, Berlin. Esakia 5:21-38

Kimoto S (1969) Notes on the chrysomelidae from Taiwan II. Esakia 7:1-68

Kimoto S (1986) The chrysomelidae (insecta: coleoptera) collected by the Nagoya university scientific expedition to Taiwan in 1984. Kurume Univ J 35:53-62

Kimoto S (1989a) The Taiwanese chrysomelidae (insecta: coleoptera) collected by Dr. Kintaro Baba, on the occasion of his entomological survey in 1983 and 1986. Kurume Univ J 38:237-272

Kimoto S (1989b) Chrysomelidae (coleoptera) of Thailand, Cambodia, Laos and Vietnam. IV. Galerucinae Esakia 27:1-241

Kimoto S, Takizawa H (1997) Leaf beetles (chrysomelidae) of Taiwan. Tokai Univ. Press, Tokyo, p 581

Maulik S (1936) The fauna of British India, including Ceylon and Burma, Coleoptera. Chrysomelidae (galerucinae). Taylor and Francis, London, p 648

Medvedev LN (2011) A contribution to the knowledge of oriental species of cneorane baly, 1865 (chrysomelidae, galerucinae). Entomol Basil Coll Frey 33:351-368

Medvedev LN, Zaitzev YM (1977) Larval morphology in the genus cneorane (coleoptera, chhrysomelidae). In: Dubeshko LN (ed) Fauna and ecology of insects in Siberia and Far east. Zhdanov Irkutsk Univ, Irkutsk, Russia, p 199 (in Russian)

Ogloblin DA (1936) Listoedy, galerucinae. Fauna SSSR. Nasekomye zhestkokrylye [chrysomelidae, galerucinae. Faune de l'URSS, insectes coléoptères], n. s. 8, 23 (1). Izdatel'stvo Akademii Nauk SSSR, Moskva-Leningrad, p 455, in Russian

Takizawa H, Nakamura S, Kojima K (1995) The Taiwanese chrysomelid beetles preserved in hiwa museum for natural history (chrysomelidae: coleoptera). Misc Rep Hiwa Mus 33:1-16 (in Japanese)

Wang J, Yang X, Wang S, Wu Y, Li W (1998) Fauna of chrysomelidae of wuyishan nature reserve in China. China Forestry Publishing House, Beijing, p 213 (in Chinese)

Weise J (1889) Insecta, a cl.G. N. Potanin in China et in Mongolia movissime lecta. IX. Chrysomelidae et coccinellidae. Horae Soc Entomol Ross 23:560-663

Weise J (1922) Chrysomeliden der Indo-Malayischen region. Tijdschr Entomol 65:39-130

Weise J (1924) Pars 78: chrysomelidae: 13. Galerucinae. In: Schenkling S (ed) Coleopterorum catalogus. W. Junk, Berlin, p 225

Wilcox JA (1971) Chrysomelidae: galerucinae (oidini, galerucini, metacyclini, sermylini). In: Wilcox JA (ed) Coleopterorum catalogus supplementa, vol 78 , 2nd edn, Pars. W. Junk, Gravenhage, Netherlands, pp 1-220, 1

Yu P, Wang S, Yang X (1996) Economic insect fauna of China, Fasc. 54. Coleoptera; chrysomeloidea (II). Science Press, Beijing, p 324, in Chinese

Zaitzev YM, Dap DT (1982) New larvae of the genus Oides and Cneorane (coleoptera, chrysomelidae, galerucinae) from Vietnam. In: Medvedev LN (ed) Animal world of Vietnam. Nauka, Moscow, p 168, in Russian

doi:10.1186/1810-522X-52-9

Cite this article as: Lee and Bezděk: The genus Cneorane Baly, 1865 from Taiwan (Coleoptera: Chrysomelidae: Galerucinae), with notes on sexual dimorphism and its life history. Zoological Studies 2013 52:9.

\section{Submit your manuscript to a SpringerOpen ${ }^{\circ}$ journal and benefit from:}

- Convenient online submission

- Rigorous peer review

- Immediate publication on acceptance

- Open access: articles freely available online

- High visibility within the field

- Retaining the copyright to your article

Submit your next manuscript at $>$ springeropen.com 